\title{
Proceeding
}

Supplementary Issue: Winter Conferences of Sports Science. Costa Blanca Sports Science Events, 24 April 2020. Alicante, Spain.

\section{From biomechanics to learning: Continuum for the theory of physical and sports education}

\author{
FELICE DI DOMENICO \\ Department of Human, Philosophical and Educational Sciences, University of Salerno, Italy
}

\begin{abstract}
The structures of the human body allow biomechanical movements in a series of kinetic sequences. The study of movement is often characterized by the excessive use of new technologies that also invade dynamics with deterministic hypotheses that are only of computer engineering and only for diagnostic aspects of bioinformatics. Biomechanics is therefore often reduced to the expansion of statics and kinematics without any consideration of dynamics in the full sense of the meaning. The dynamic is the basis on which all the laws of movement are implemented, attributing a cause that includes the reaction to the stresses integrated by the decision choices of each individual person. Integration is characterized by the quality of decisions that characterize the difference between motor learning. Decisions are generated by the learning teaching processes to which every human being in developmental age is subjected. It is clear that biomechanical acquisitions can make an important contribution in the evaluation and management of problems affecting human movement, but, in an integrated way, they need other knowledge and interventions to be truly effective in their application.
\end{abstract}

Keywords: Cognitive approach; Dynamic ecological approach; Heuristic learning.

\section{Cite this article as:}

Di Domenico, F. (2020). From biomechanics to learning: Continuum for the theory of physical and sports education. Journal of Human Sport and Exercise, 15(2proc), S268-S278. doi:https://doi.org/10.14198//hse.2020.15.Proc2.18

Corresponding author. University of Salerno, Italy.

E-mail: flcdidomenico@gmail.com

Supplementary Issue: Winter Conferences of Sports Science. Costa Blanca Sports Science Events, 24 April 2020. Alicante, Spain.

JOURNAL OF HUMAN SPORT \& EXERCISE ISSN 1988-5202

(c) Faculty of Education. University of Alicante

doi:10.14198/jhse.2020.15.Proc2.18 


\section{INTRODUCTION}

Human movement is expressed through a precise chain of actions that involve several joints that follow a sequence and a unique timing for each person different from that of another and has to develop into the phenomenon, that is unique and unrepeatable (Raiola, 2013, 2014, 2015ab, 2017, 2019ab, 2020). This sequence and timing is integrated and based on muscle synergies to get the finalization of tasks skills (Altavilla, 2019, Altavilla et al, 2015ab, Raiola et al, 2018, Raiola, Di Tore, 2017). The structures of the human body, bones joined together through the joints and muscles and related tendons, allow biomechanically the movements in a set of kinetic successions (Bosch, 2015). These anatomical and physiological structures have their application references in statics and kinematics because they concern the reactions of the human body to external stresses (Bronfenbrenner, 1979). However, these aspects are emphasized by the excessive use of new technologies that also invade the dynamics with deterministic assumptions that are only of computer engineering and only for diagnostic aspects of bioinformatics (Vastola et al, 2016). In Figure 1 it can see the complexity of integrated motor system. This negative haven't compared to exergames (Viscione, D'elia, 2019, Di Tore, Raiola, 2012ab) and virtual and augmented reality (D'Elia, Raiola, 2019) because there are different applications. Biomechanics aspect is therefore often reduced to the expansion of statics and kinematics without any consideration of dynamics in the full sense of the meaning (Di Domenico, D'Isanto, 2019). The dynamic is the basis on which all the laws of the movement are implemented, attributing a cause that includes the reaction to the solicitations integrated by the decision-making choices of each individual person (Gaetano, 2012, Raiola, 2011ab, 2012). Integration is characterized by the quality of the decisions that characterize the difference between motor learning.

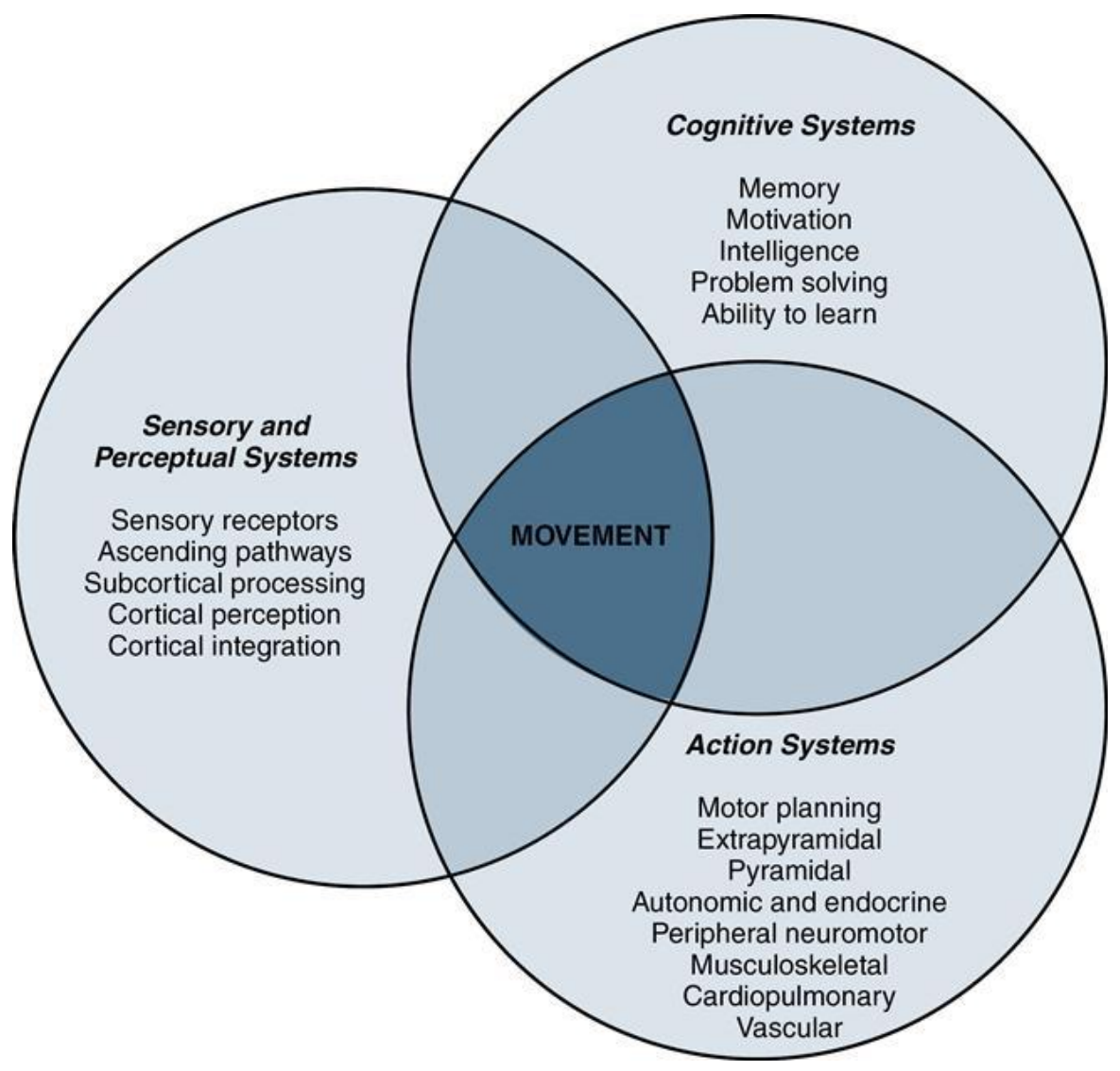

Figure 1. The complexity of the movement. 
Decisions are generated by the learning teaching processes ( $D^{\prime}$ Elia et al, 2019) to which every human being in developmental age is subjected (D'Isanto et al, 2019ab, 2017, D'Isanto, 2016). Hence, the learning of motor gestures is possible through particular methodologies in particular ontogenetic phases of the individual's life. In the study and evaluation of movements it is not possible to consider the human body simply as a system of levers and controls in view of a specific action. A purely mechanistic view would lead to an anachronistic Cartesian body-mind dualism, as it is often exalted in bioengineering and bioinformatics applications. Bernstein (1935) already affirmed the close dependence between nerve impulses and movements. He addresses the issue of motor learning with the introduction of the concept of the "problem of degrees of freedom". This problem would be solved by freezing, during the early stages of the acquisition of the skill, the non-essential parts, thus reducing the degrees of freedom to focus on the essence of the motor task. Skill development would coincide with the release and management of degrees of freedom according to the three phases of reduction, exploration and capitalization. The reduction of the degrees of freedom allows the motor task (skill) to be accomplished by blocking only one joint to allow limited articulation of the entire motor gesture and thus achieve the objective stably in rough form. The exploration of new degrees of freedom, on the other hand, is carried out by the search for refinement of the raw movement in the sense of greater precision in achieving the goal and daring new balances by freeing the blocked joint and exploring other blockages and new joint and muscular commitments. This phase is often governed by educational processes and learning contexts that artificially vary to have a greater fine execution and respond to the demands of the surrounding environment. Lastly, there is the capitalization phase which is the definitive complete gesture that gathers the kinaesthetic perceptions of the reduction and exploration of the degrees of freedom and optimizes them in the free and spontaneous interaction with the variables of the phenomenon in the shortest possible time. The study of human movement, i.e. biomechanics (consisting of static, kinematics and dynamics) and the bioenergetics that gives propulsion to movement, are inconclusive if the non-measurable determinants of movement itself are also not taken into consideration: cognitive and psychological aspects, without which the study of movement would be sterile and indicative only of some aspects concerning joint physiology or the mechanical laws that regulate it. And therefore, he reiterates the problem of the measurement drift of computer engineering and bioengineering with the surrogate fashions of robotics, augmented and virtual reality. The objective of the study is to clarify, through the review of the scientific literature and psychological and pedagogical argumentative deductions, the close relationship between the mode of execution of a motor gesture (of daily life or sports performance), of biomechanical interest, and the processes which led to the level of acquisition of motor learning, that is, all that is inherent in the learning processes. Reference will be made to the theories of motor learning and to the various study approaches in order to understand what the components are, both internal and environmental, and the physiological and cognitive mechanisms that lead to the assimilation of motor skills.

\section{BIOMECHANICS}

In Figure 2 it can see usual application of new technology for a current and ordinary movement analysis example. Hatze (1974) in one of his publications in the journal of Biomechanics defined biomechanics "as the study of the structure and functionality of biological systems carried out through mechanical analysis systems". A few years later the European Society of Biomechanics was founded which defines biomechanics as the study of the forces that act on or are generated by a body and the effects of these forces on tissues, fluids or materials for research purposes, diagnosis and treatment (Hamill et al., 2015). Ultimately, biomechanics applies acquisitions and the laws of mechanics to the study of living organisms. It is an interdisciplinary science that contributes significantly to the study of the knowledge of human movement (Neumann, 2017). 


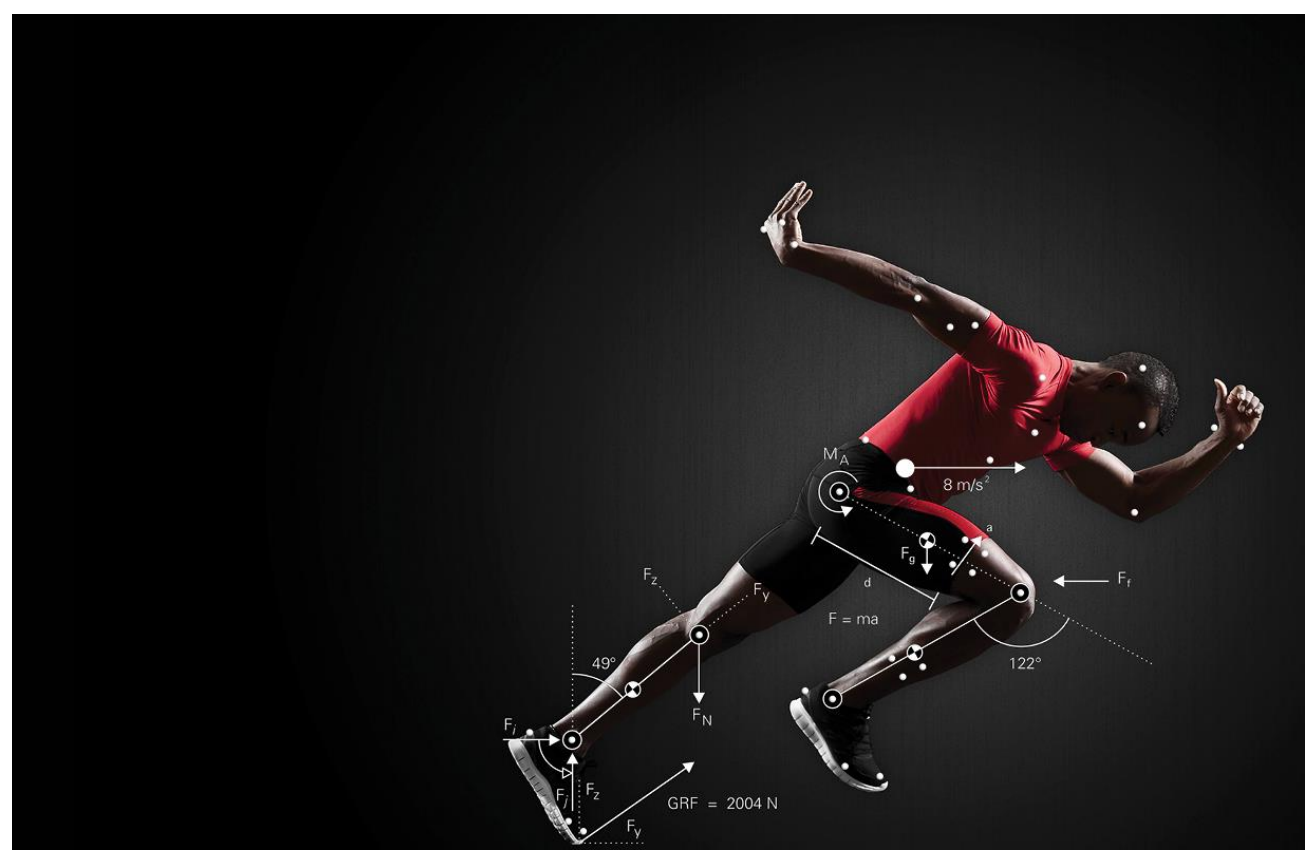

Figure 2. Biomechanics.

The fields of application of biomechanics are manifold: from bioengineering, to orthopaedic medicine, from the sciences that are interested in training methodology to clothing. Classical mechanics, which deals with inert bodies and tendentially stable models, are not always applicable to the study of biological phenomena such as human movement (Puglisi, 2016). Classical mechanics deals with stable systems and, once the initial conditions are decided, everything else follows in a deterministic way. The bodies of the living are not invariant systems. Biomechanics does not simply describe the movements of the human body through the identification of mechanical, mathematical and model aspects, typical of engineering studies, but it investigates the cognitive mechanisms that made it possible to perform a certain gesture, in addition to defining the unique and particular qualities that living fabrics have. The human body is a complex system and in continuous relationship with nonlinear variables and, as such, it must continually face a succession of events (Latash, 2012). In fact, a certain movement pattern cannot be standardized to all human beings. The numerous variables to consider in evaluating a certain motor gesture are not always easy to understand. Among them it is appropriate to include anthropometric measurements, muscle morphology, the number of muscle fibres (twitch) and the type, arrangement and quantity of elastic elements in series and in parallel and subsequently timing. to which must be added the cognitive mechanisms that always intervene in the planning, execution and correction of motor gestures.

\section{MOTOR CONTROL}

The correct execution of a movement (from a biomechanical point of view) is the result of the correct synchronism in terms of rhythm, or timing, of activation of all the components that characterize it in response to stimuli of various kinds (Nicoletti, Borghi, 2007, Pirola, 2012). The motor control models that emerged from the various studies are essentially two, with essentially opposite characteristics: closed circuit motor control (von Holst 1954) and open circuit motor control (Schmidt 1975, James 1890, Schmidt and Wrisberg 2008). Closed-loop motor control essentially depends on some sensory information called feedback produced by movement, or simply feedback. Feedback has the function of updating, modifying and correcting the body 
posture in real time. This sensory information is compared with the initial objective of the movement allowing to detect and correct any errors. The closed circuit control model is advantageous since it allows the implementation of a series of strategies related to the task giving flexibility to the system; however, this model is inadequate for those movements that are not performed in sufficiently long times, as it has been shown that, in order for the feedback to be perceived and processed before the movement is completed, the time required to act a correction is approximately $150-200 \mathrm{msec}$ (Gao and Zelaznik, 1991). This model is suitable for informed information processing processes. However, closed circuit mechanisms that do not require attention and that occur in times of less than 200 milliseconds should be considered. Schmidt (2000) considers the existence of closed-circuit control circuits with faster feedback. These circuits are represented by the spinal reflexes divided into reflexes of muscle elongation and in neuronal circuits of the strength and length of the muscle and of the position and movement of the limbs. The open circuit motor control model (Schmidt, Wrisberg, 2008) does not respond to any feedback as the instructions are organized in advance and are carried out regardless of the effects they may have on the environment. The action is not subject to adjustments in progress; therefore, the system is effective as long as the environmental circumstances remain unchanged. Figure 3 is the scheme of Schimdt, Lee ( and Hodges.

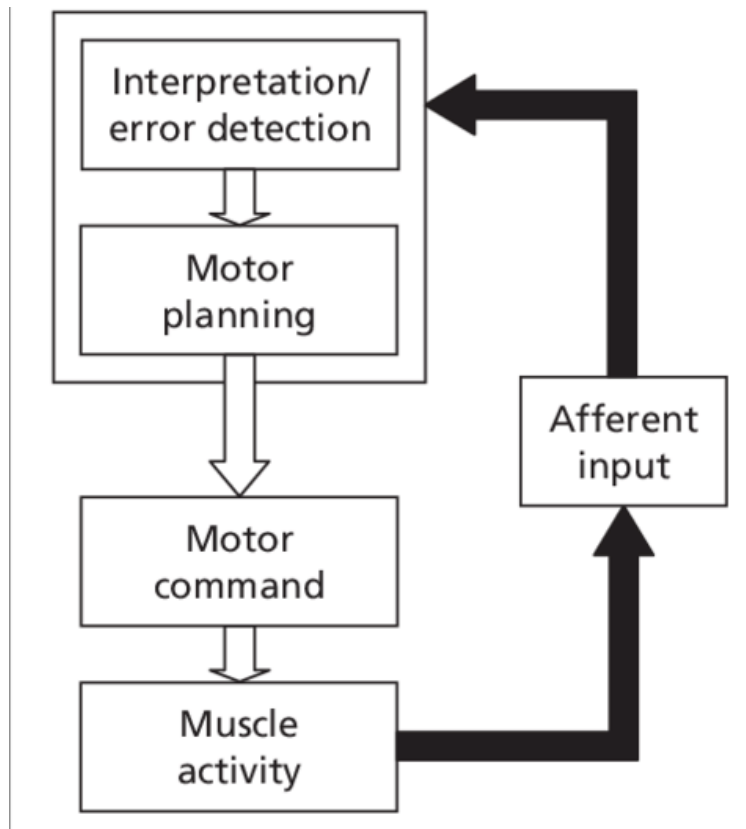

(a)

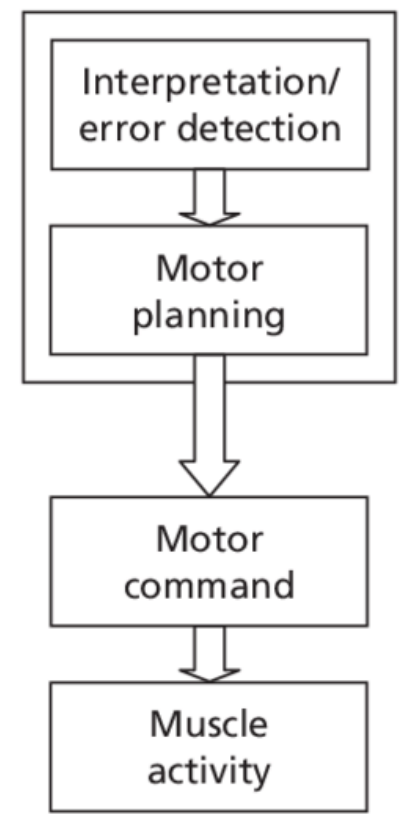

(b)

Figure 3. (a) Closed-loop control system. (b) Open-loop control system (Schmidt \& Lee 1999, after Hodges, 2003).

The cognitive theory of motor learning derives directly from the integration of open and closed-circuit motor control. The generalized motor program "is a motor program that defines a movement pattern; this flexibility allows it to be adapted so as to produce variations of the motor pattern adapted to modified demands of the environment "(Schmidt, Wrisberg, 2000). The idea of the existence of motor programs (Brooks 1979, Henry \& Rogers 1960, Keele 1968, 1986, Keele, Cohen \& Ivry 1990, Lashley 1917, Schmidt 1975, 1988) is supported by Nikolaj Bernstein, who underlined the difficulty of closed circuit model, and any other model according to which the contractions of the different muscles are managed directly by the upper centres. This would create a problem for the system to have to check too many independent states simultaneously. These 
independent states are called degrees of freedom. The motor programs are able to control the different degrees of freedom, independent of each other, so that they can work as a single unit. In this way, the task of the higher centres is limited to checking the selection of a specific motor program and starting it at the right time. Many authors believe that imagination and observation can also play a role in the learning or re-learning process in case of damage to the nervous system. They are theories of ecological orientation methodologies that dynamically create learning through interaction with the environment. These theories are confirmed by various studies that demonstrate that the motor system is activated both during the execution of the gesture, and during the observation and imagination of the movement (motor imagery). The first evidence of the existence of a Mirror circuit dates back to the studies conducted with EEG in 1950 by Gastaut and to those conducted in 1982 by Hyvarinen on the posterior parietal lobe, but certainly the real discovery of mirror neurons is due to Rizzolatti and coll. in 1996. Mirror neurons are a particular class of visuo-motor neurons that are activated both when the individual performs a certain action and when he observes another individual performing such an action.

\section{MOTOR LEARNING THEORIES}

In general, learning can be defined as a relatively lasting and stable modification of behaviour following an experience, usually repeated several times over time (Figure 4). The meaning of motor learning consists in the assimilation and acquisition of movements or parts of them, previously not owned, which must then be stabilized (Meraviglia, 2012).

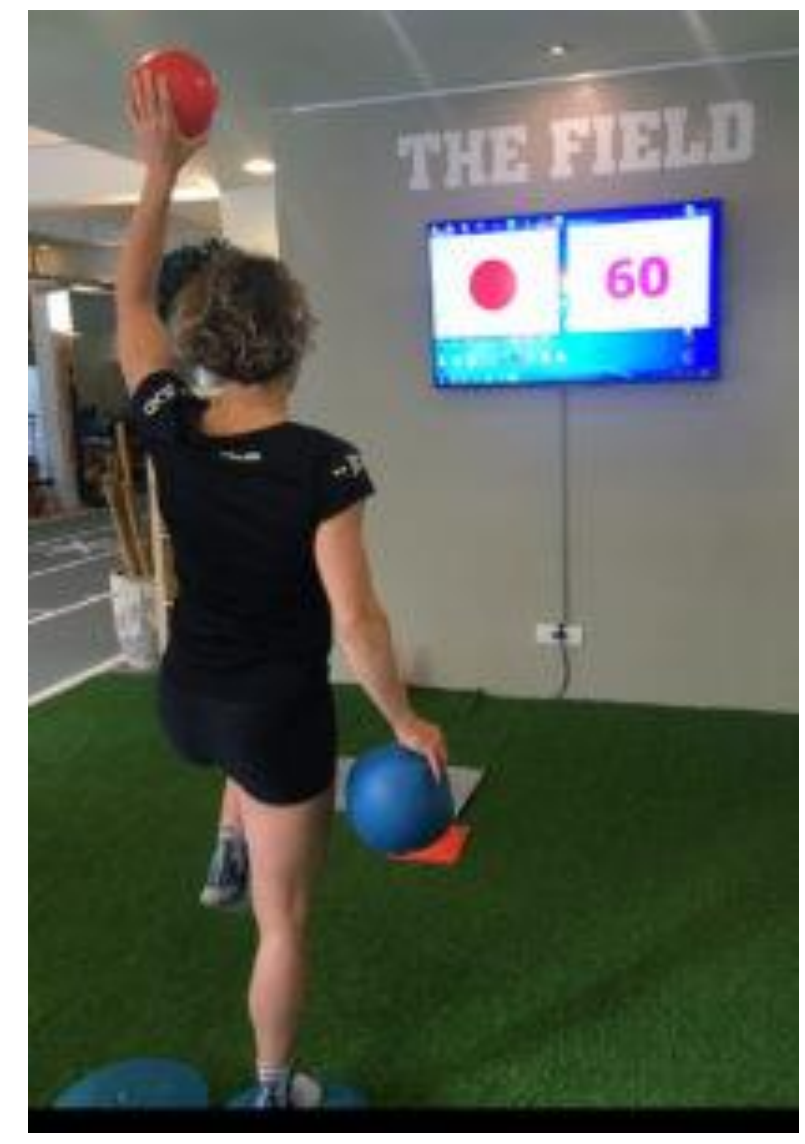

Figure 4. Motor learning through training. 
These learned and consolidated movements are called Skills. For Meinel (Meinel et al, 2010) skills are actions that are consolidated mainly through repeated exercise, which take place, at least in part, automatically, that is, without attention being intentionally concentrated on them. For Guthrie (1952) "skill consists in the ability to achieve some final results with the utmost certainty and the least waste of energy or time ..." Motor learning takes concrete form through the succession of three stages which include:

1. Cognitive or raw Coordination stage: phase of understanding the task in which considerable cognitive activity is required as the subject must choose the most appropriate strategies to perform the required task.

2. Stage of consolidation or fine coordination: perfecting the task in which the subject has determined the most effective way to perform the task.

3. Autonomous stage or Variable availability phase: ability to arrange movement automatically in response to certain environmental inputs.

The ontogenetic process of motor learning also materializes through the gradual maturation of the nervous system (Mandolesi, 2012). The maturation of the nervous system is a process that affects specific phases of human life, from before birth and in a non-linear way. It is clear that adolescents show less reactivity of the amygdala and frontal cortex, compared to adults, when faced with exposure to adverse stimuli, dangers or punishments.

Table 1. Motor learning stages (own source).

\begin{tabular}{|c|c|c|c|}
\hline Stage & Process & Characteristics & Other name \\
\hline Cognitive & Gathering information & Large gains, inconsistent performance & Verbal-motor stage \\
\hline Associative & Putting actions together & $\begin{array}{l}\text { Small gains, disjointed performance, } \\
\text { conscious effort }\end{array}$ & Motor stage \\
\hline Autonomous & Much time and practice & $\begin{array}{l}\text { Performance seems unconscious, } \\
\text { automatic, and smooth }\end{array}$ & Automatic stage \\
\hline
\end{tabular}

There are several authors who have formulated theories with the aim of drawing an exhaustive picture regarding human learning processes and mechanisms. Cognitivists, for example, believe that the human being has, at the brain level, a series of motor programs, or sequences of commands that, at the central nervous system level, coordinate the execution of movements. Learning movements consists in developing cognitive structures, called motor programs, through information processing processes. These motor programs would be able to influence the activity of the different degrees of freedom (Bernstein's degree of freedom problem), independent of each other, so that they can work as a single unit. These processes allow the possibility to compare in real time, closed-circuit motor control (Adams 1971), or subsequently, opencircuit motor control (Schmidt 1975, Schmidt and Wrisberg 2008), obtained results and expected results, triggering a correction process of motor execution. Another approach, called the ecological approach, considers learning as a progressive and mutual adaptation between the active development of the human being and the environmental varieties in which the individual lives and develops. The main contribution to an ecological vision in psychology was that of Bronfenbrenner (1979), who developed the PPCT "processperson-context-time" model. For supporters of the ecological and dynamic approach, the use of prescriptive mental structures is not necessary at all because they consider movement to be a process of self-organization aimed at effective execution while respecting the structural characteristics of the subject in relation to the external environment (Figure 5). 


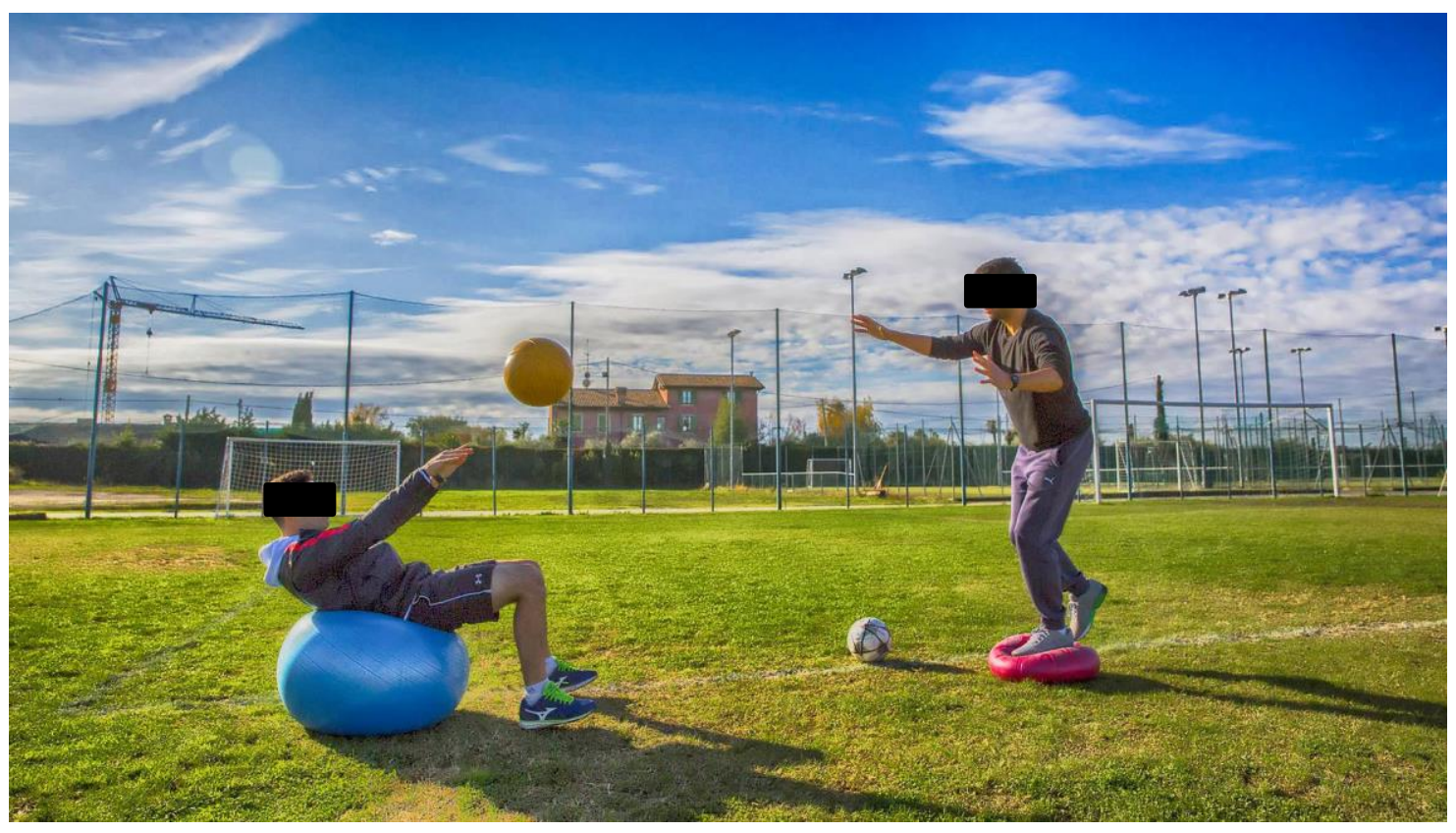

Figure 5. Environmental adaptation (own source).

The action is directly available to the subject who acts in a given environment, the sensorimotor system has the ability to organize itself and therefore the use of a motor program is not necessary (Eldeman, 1987). In confirmation of what has been said, Bosh (2015) also states that complex systems can be highly organized and adaptive even without any means of central control. The dynamic interactions between the parts of the system cause the system to be attracted to certain states which are advantageous under certain conditions. So, the system would show intelligent and adaptive behaviour even without a single part of the system that really "knows" what it is doing.

\section{CONCLUSIONS}

The review of the scientific literature shows the importance of a holistic vision with respect to the treatment of the action referring to complex dynamic systems, such as those referring to man erectus. The theory of dynamic systems is in contrast with the more reductionist, deterministic and mechanistic visions referable to technological and IT systems where decision making, and arbitrariness is absent. The theory of dynamic systems has so far shown that it can legitimately be considered a unitary and coherent frame of reference for the study of numerous disciplines, including the study of human movement. On the basis of what has been said, it is clear that the acquisitions of biomechanics can make an important contribution in the evaluation and management of problems affecting human movement, but, in an integrated way, they need other knowledge and interventions in order to be truly effective in their application. These are psychological and respond to requests from the context in which the dynamic system is immersed with interactions between the variables in an irregular circular way. The movement, therefore, must be understood as the sum of mechanisms that take place within a complex system in which all its parts interact in a significant and absolutely unpredictable way except with the analysis of exogenous elements to the deterministic mechanisms of physics and mechanics. The motor activity of living organisms is the manifestation of integrations of the organism itself with the environment that surrounds it and the motor control is distributed between different systems that interact with each other, cooperating to achieve behaviour appropriate to the 
required circumstances: nervous system, muscle and skeletal, external forces, gravity and inertia, such as it is representing in Figure 6.

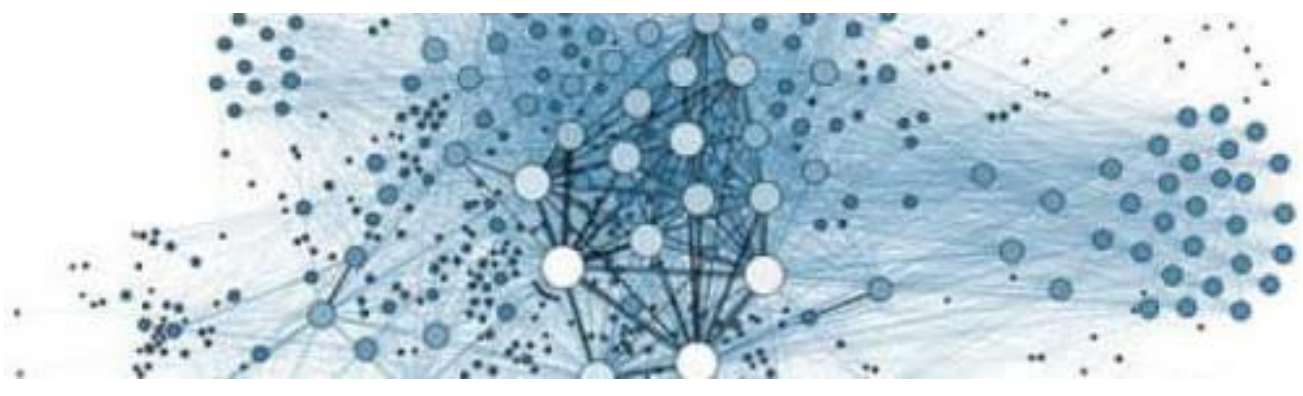

Figure 6. Complex dynamic systems (own source).

We must consider the characteristics of the system that is moving, the internal and external forces acting on the body, and the variations with respect to the initial conditions. The motor synergies are therefore the basis of the generation of movements and the flexibility of the neural systems allows to manipulate these synergies to constitute motor strategies and, that is, the selection of a particularly suitable synergy to achieve a certain purpose.

\section{REFERENCES}

Adams, J.A. (1971). A closed-loop theory of motor learning. Journal of Motor. Behavior, 3:111-15.

Altavilla, G. (2019). Monitoring training to adequate the teaching method in training: An interpretative concepts, Journal of Physical Education and Sport, 19, art. no. 258, pp. 1763-1766.

Altavilla, G., Forte, D., D'isanto, T. (2019). Self-physical and emotional perception in volleyball for drop out, Journal of Human Sport and Exercise, 14 (Proc4), pp. S1022-S1029. https://doi.org/10.14198/ihse.2019.14.proc4.64

Altavilla, G., Furino, F., Marika, D.P., Raiola, G. (2015a). Physical skills, sport learning and socio-affective education, Sport Science, 8, pp. 44-46.

Altavilla, G., Furino, F., Di Palmo, M., Raiola, G. (2015b). The child hypokinetic and the overtrained, Sport Science, 8, pp. 72-74.

Bosch, F. (2015). Strength training and coordination: an integrative approach, Uitgevers.

Bronfenbrenner, U. (1979). The Ecology of Human Development, Harvard College, USA.

Cohen, A., Ivry, R. I., \& Keele, S. W. (1990). Attention and structure in sequence learning. Journal of Experimental Psychology: Learning, Memory, and Cognition, 16(1), 17-30. https://doi.org/10.1037/0278-7393.16.1.17

Brooks, V.B.(1979). Motor programs revisited, posture and movement.

D'Elia, F., Raiola, G. (2019). Sport and Exercise Sciences Degrees in Italy: Comparison Between Online and Traditional Teaching Models, Communications in Computer and Information Science, 1091, pp. 209-216. https://doi.org/10.1007/978-3-030-31284-8_16

Di Domenico, F., D'isanto, T., (2019). Role of speed and agility in the effectiveness of motor performance, Journal of Physical Education and Sport, 19, art. no. 271, pp. 1836-1842.

D'Isanto, T., D'Elia, F., Raiola, G., Altavilla, G. (2019a). Assessment of sport performance: Theoretical aspects and practical indications, Sport Mont, 17 (1), pp. 79-82.

D'Isanto, T., Pisapia, F., \& D'Elia, F. (2019b). Running and posture. Journal of Human Sport and Exercise, 14(4proc), S1058-S1064. https://doi.org/10.14198/hhse.2019.14.Proc4.68 
D'Isanto, T. (2016). Pedagogical value of the body and physical activity in childhood [Pedagoška vrijednost tijela i tjelesne aktivnosti u djetinjstvu]. Sport Science, 9, pp. 13-18.

D'Isanto, T., Altavilla, G., Raiola, G. (2017), Teaching method in volleyball service: Intensive and exenstive tools in cognitive and ecological approach, Journal of Physical Education and Sport, 17, art. no. 233, pp. 2222-2227.

Di Tore, P.A., Raiola, G. (2012a). Exergame-design and motor activities teaching: An overview of scientific paradigms on motor control, Mediterranean Journal of Social Sciences, 3 (11), pp. 119122.

Di Tore, P.A., Raiola, G. (2012b). Exergames in motor skill learning, Journal of Physical Education and Sport, 12 (3), pp. 358-361.

Edelman, G. M. (1987). Neural Darwinism: The theory of neuronal group selection. Basic Books.

Gaetano, R. (2012). Motor learning and didactics into physical education and sport documents in middle school-first cycle of education in Italy. Journal of Physical Education and Sport, 12 (2), pp. 157-163.

Gastaut, H. (1950). Ėvidence électrographique d'un mécanisme sous-cortical dans certaines épilepsies partielles-la signification clinique des "secteurs eréo-thalamiques". Rev Neurol 83:396-401.

Guthrie, E.R. (1952). The psychology of learning, Harper \& Row, New York.

Hamill, J., Knutzen, K. M., Derrik, T., (2014). Biomechanical Basis of Human Movement, Wolters Kluwer.

Henry, F. M., \& Rogers, D. E. (1960). Increased response latency for complicated movements and a "memory drum" theory of neuromotor reaction. Research Quarterly of the American Association for Health, Physical Education, \& Recreation, 31, 448-458. https://doi.org/10.1080/10671188.1960.10762052

Hyvärinen, J. (1982). The Parietal Cortex of Monkey and Man, Springer-Verlag Berlin Heidelberg.

Keele, S. W. (1968). Movement control in skilled motor performance. Psychological Bulletin, 70(6, Pt.1), 387-403. https://doi.org/10.1037/h0026739

Lashley, K. S. (1917). The accuracy of movement in the absence of excitation from the moving organ. American Journal of Physiology, 43, 169-194. https://doi.org/10.1152/ajplegacy.1917.43.2.169

Latash, M. L. (2012). Progress in Motor Control: Bernstein's Traditions in Movement Studies, Vol. 1.

Mandolesi, L. (2012). Neuroscienze dell'attività motoria: Verso un sistema cognitivo-motorio, Springer, Milano. https://doi.org/10.1007/978-88-470-2625-4_2

Meinel, K., Schnabel, G., Gulinelli, M. (2000). Teoria del movimento. Abbozzo di una teoria della motricità sportiva sotto l'aspetto pedagogico, Società Stampa Sportiva.

Meraviglia, M. V. (2012). Sistemi motori, nuovi paradigmi di apprendimento e comunicazione, SpringerVarlag, Milano, pag. 33. https://doi.org/10.1007/978-88-470-1995-9_7

Neumann, D. (2017). Kinesiology of the Musculo-Skeletal system, Third edition, Elsevier, Missouri, USA.

Nicoletti, R., Borghi, A. M. (2007). II Controllo Motorio, II Mulino, Bologna.

Pirola, V. (2012). II movimento umano, Edi Ermes.

Puglisi, F. (2006). Biomeccanica, Marrapese editore, Roma.

Raiola, G. (2020). The Movement and Sport Science in Italy Towards the European Research Council, Physical Culture and sport. Studies and research vol. 86. https://doi.org/10.2478/pcssr-2020-0011

Raiola, G. (2019a). Comparison of exercise and sport sciences epistemology between european research council structure panel and Italian academic system Sport Science, 12, pp. 112-120.

Raiola, G. (2019b). Complex study for an epistemology of exercise and sport sciences: A)keyconceptsofboth ERC subpanels and CUN keywords; b) physical training and sport methodology sciences academic disciplines in pedagogy recruitment sector and biomedical one: A correlationships study, Journal of Physical Education and Sport, 19, art. no. 255, pp. 1748-1754. 
Raiola, G., D'elia, F., Altavilla, G. (2018). Physical activity and sports sciences between European Research Council and academic disciplines in Italy. Journal of Human Sport and Exercise, 13, pp. S283-S295. https://doi.org/10.14198/jhse.2018.13.proc2.13

Raiola, G., (2017). Motor learning and teaching method, Journal of Physical Education and Sport, 17, art. no. 236, pp. 2239-2243.

Raiola, G., Di Tore, P.A., (2017). Motor learning in sports science: Different theoretical frameworks for different teaching methods, Sport Science, 10, pp. 50-56.

Raiola, G. (2015). Sport skills and mental health. Journal of Human Sport and Exercise, 10(1proc), S369S376. https://doi.org/10.14198/jhse.2015.10.Proc1.27

Raiola, G. (2014). Motor control and learning skills according to cognitive and ecological dynamic approach in a vision on behaviorism, cognitive, Gestalt and phenomenology theories, Mediterranean Journal of Social Sciences, 5 (15), pp. 504-506. https://doi.org/10.5901/mjss.2014.v5n15p504

Raiola, G. (2013). Body knowledge and motor skills, Knowledge Cultures, 1 (6), pp. 64-72.

Raiola, G. (2011a). A study on Italian primary school rules: Neurophysiological and didactics aspects $n$ physical education and sport. Journal of Physical Education and Sport, 11 (2), pp. 43-48.

Raiola, G. (2011b). Study between neurophysiological aspects and regulation documents on preschool in Italy, Journal of Physical Education and Sport, 11 (1), pp. 42-47.

Rizzolatti, G., Fadiga, Gallese V, Fogassi L. (1996). Premotor cortex and the recognition of motor actions, Cognitive brain research 3 (2), 131-141. https://doi.org/10.1016/0926-6410(95)00038-0

Schmidt, R. A. (1975). A schema theory of discrete motor skill learning. Psychological Review, 82(4), 225-260. https://doi.org/10.1037/h0076770

Schmidt, R. A. (1988). Motor control and learning: A behavioral emphasis (2nd ed.). Human Kinetics Publishers.

Schmidt R.A., Lee T.D., (2012). Controllo motorio e apprendimento, la ricerca sul comportamento motorio, Calzetti e Mariucci, Torgiano.

Schmidt, R. A., \& Wrisberg, C. A. (2008). Motor learning and performance: A situation-based learning approach (4th ed.). Human Kinetics.

Schmidt R. A., Craig A. Wrisberg, Apprendimento motorio e prestazione, S.S.S., Roma, 2000 - pag. 140.

Vastola, R., Coppola, S., Sibilio, M. (2016). Motion Analysis Technologies for Biomechanical Gait and Postural Analysis in Ballet. Journal of Sports Science, vol. 4, p. 241-246. https://doi.org/10.17265/2332-7839/2016.04.008

Viscione, I., D'elia, F. (2019). Augmented reality for learning in distance education: The case of e-sports, Journal of Physical Education and Sport, 19, art. no. 304, pp. 2047-2050.

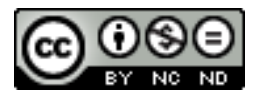

This work is licensed under a Attribution-NonCommercial-NoDerivatives 4.0 International (CC BY-NC-ND 4.0). 